\title{
Munida casadioi (Schweitzer \& Feldmann, 2000) from the Eocene of the Bariloche area, Patagonia (Argentina)
}

\author{
Alessandro Garassino ${ }^{1}$ \& Antonio De Angeli ${ }^{2}$ \\ 'Dipartimento di Paleontologia degli Invertebrati, Museo civico di Storia naturale, C.so Venezia 55, I-20121 \\ Milano, Italy; ${ }^{2}$ Associazione Amici del Museo ëG. Zannatoí, Piazza Marconi, 15, I-36075 Montecchio \\ Maggiore (Vicenza), Italy
}

Keywords: Crustacea, Anomura, Eocene, Argentina

\begin{abstract}
New material forces a reconsideration of Austromunida casadioi Schweitzer \& Feldmann, 2000. Originally the type species of a new genus, we find that this is only a species of the genus Munida Leach, 1820.
\end{abstract}

\section{Introduction}

Schweitzer \& Feldmann (2000) erected the new genus Austromunida (type species: $A$. casadioi) on the basis of three more or less complete specimens (holotype: GHUNLPam 16832; paratypes: GHUNLPam 16833, 16834; Geological Museum, Universidad nacional de La Plata) from the middle Eocene Centinela Formation on Estancia 25 de Mayo, Calafate, Santa Cruz (Argentina). Although the authors did note the superficial similarity to Munida Leach, 1820 , they justified the erection of the new genus on features not present in all other known fossil galatheids, e.g., the narrow, needle-like rostrum, transverse ridges and numerous lateral spines.

However, the recent discovery of a rich assemblage of galatheids in the Bariloche area (Dipartimento di Paleontologia degli Invertebrati, Museo civico di Storia naturale di Milano, work in progress), casts doubts over the validity of the genus Austromunida. Some of these specimens show the needlelike rostrum, identical to the ones seen in material from Calafate, and as a consequence this feature might be used to refer these specimens to Austromunida. However, two individuals have well-developed supraorbital spines. These are not present in $A$. casadioi, but this may be a preservational matter: the frontal region of the carapace is poorly preserved, which might give the impression of their absence (see also Schweitzer \& Feldmann, 2000, fig. 4).

\section{Austromunida}

A new study of casts of holotype and paratypes of A. casadioi (Geology Department, Kent State University, Kent, Ohio) has now revealed the presence of small epigastric spines, not shown in fig. 4 of Schweitzer \& Feldmann (2000), and has shown that the arrangement of transverse ridges is different from that shown in the same illustration. In most of the Bariloche specimens, two or three strong epigastric spines are seen as well as transverse ridges in an arrangement identical to that recorded for material from Calafate. Cervical and branchiocardiac grooves are well developed both in A. casadioi and in the present specimens, and epibranchial regions are well marked. Moreover, several small spines along the anterolateral and lateral margins are visible in material from Calafate and Bariloche.

As pointed out by some authors (Beneditct, 1902; Chace, 1942; Zariquiey Alvarez, 1968; Macpherson \& de Saint Laurent, 1991; Macpherson, 1994, 1995; Schweitzer \& Feldmann, 2000), extant and fossil species of Munida have some characters in common with species in other galatheid genera, e.g., epigastric spines or small spines along the anterolateral and lateral carapace margins. One feature in particular distinguishes them from all Recent and fossil genera known to date: the needle-like ros- 


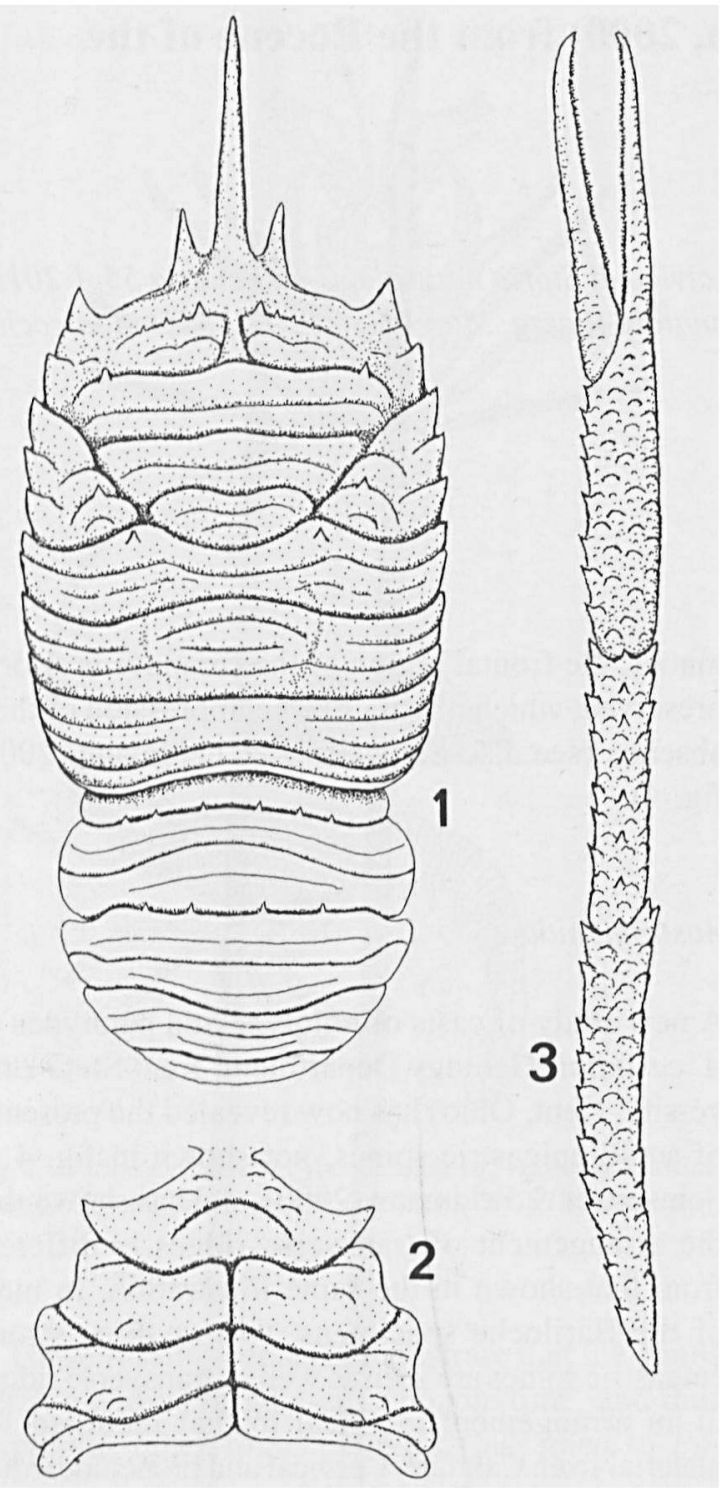

Fig. 1. Munida casadioi (Schweitzer \& Feldmann, 2000), reconstruction based on material from the Bariloche area, Patagonia; 1 - carapace and abdomen; 2 - triangular sternal plastron; 3 pereiopod I. trum with one pair of short supra-orbital, needlelike spines. The presence of this character in some specimens from Bariloche favors their placement in Munida. Moreover, since these specimens share some morphological characters with material from Calafate, e.g., needle-like rostrum, epigastric spines, small spines along antero-lateral, and lateral carapace margins and arrangement of transverse ridges, we are of the opinion that Austromunida is a junior synonym of Munida. Further support for this statement comes from the fact that the Calafate and Bariloche assemblages are of coeval stratigraphic age (middle Eocene), despite their being far apart.

\section{References}

Benedict JE. 1902. Descriptions of a new genus and fortysix species of crustaceans of the family Galatheidae, with a list of the known marine species. Proc. U.S. Natn Mus. 26: 243-334.

Chace FA. 1942. Reports on the scientific results of the Atlantis expeditions to the West Indies, under the joint auspices of the University of Havana and Harvard University. The Anomuran Crustacea. I. Galatheidea. Torreia 2: 1-106.

Macpherson E. 1994. Crustacea Decapoda: Studies on the genus Munida Leach, 1820 (Galatheidae) in New Caledonian and adjacent waters with description of 56 new species. Mèm. Mus. natn Hist. nat. Paris 161: 421-569.

Macpherson E. 1995. Crustacea Decapoda: species of the genera Munida Leach, 1820 and Paramunida Baba, 1988 (Galatheidae) from the seas around the Wallis and Futuna Islands. Mèm. Mus. natn Hist. nat. Paris 168: 387-421.

Macpherson E, de Saint Laurent M. 1991. Galatheid crustaceans of the genus Munida Leach, 1820 from French Polynesia. Bull. Mus. natn Hist. nat. Paris (4)13: 373422.

Schweitzer CE, Feldmann RM. 2000. First notice of the Chirostylidae (Decapoda) in the fossil record and new Tertiary Galatheidae (Decapoda) from the Americas. Bull. Mizunami Fossil Mus. 27: 155-173.

Zariquiey Alvarez R. 1968. Crustaceos decapodos ibèricos. Invest. Pesq. 32: xv+510 pp.

Received: 2 March 2003 